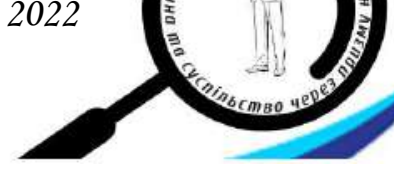

УДК 339.338:328.185:336-049.Б](477)

https://doi.org/10.52058/2786-5274-2022-1(3)-81-98

Антоненко Валентина Миколаївна кандидат економічних наук, доцент, доцент кафедри управління i фінансово-економічної безпеки, ДВНЗ «ДонНТУ», пл. Шибанкова, 2, м. Покровськ, 85300, тел.: (06239)20-309, https://orcid.org/0000-0002-8220-5813

Сервачук Михайло Олександрович магістрант, ДВНЗ «ДонНТУ», пл. Шибанкова, 2, м. Покровськ, 85300, тел.: (06239)20-309

\title{
КОРУПЦЙНІ РИЗИКИ ПРИ ДЕРЖАВНИХ ЗАКУПІВЛЯХ ТА ЇХ ВПЛИВ НА ФІНАНСОВУ БЕЗПЕКУ ДЕРЖАВИ
}

Анотація. Європейський шлях України та їі намагання стати сучасною цивілізованою державою, яка б відповідала принципам справедливого i прозорого функціонування державних фінансів, вимагає від нашої країни рішучих перетворень у сфері державного фінансування. Проте накопичені десятиліттями проблеми у цій сфері гальмують означені перспективи для України. Однією, причому загальновизнаною, проблемою є наявність і стійке живуче пролонгування корупційних ризиків у системі державних фінансів, що вельми негативно впливає, перш за все, на систему державних закупівель. Тому надто важливими на сьогодні $\epsilon$ визначення вказаних ризиків, аби це сприяло б ефективному реформуванню державних закупівель. Для цього необхідно здійснити оцінку рівня корупційності системи публічних закупівель, сучасного стану iii функціонування, провести систематизацію можливих ризиків недоброчесної поведінки суб'єктів на різних етапах проведення торгів. Це дало б можливість визначитися із способами їх мінімізації, аби забезпечити адекватне реформування тендерного законодавства та практики дієвої протидії зазначеним вище ризикам. Для вирішення поставлених завдань в роботі досліджено корупційні ризики при проведенні державних закупівель та визначено їх вплив на безпеку держави. Звернено увагу на чинники, від яких залежить потенційна дієздатність фінансових ресурсів України за сучасних умов, 3 огляду на необхідність забезпечення захисту фінансових інтересів держави і суспільства. Досліджено діюче законодавство у сфері регулювання державних фінансів через систему ProZorro та проведено аналіз стану виконання державних закупівель із визначенням результатів та наслідків їх проведення. Визначено фактори, які негативно впливають на процес державних закупівель, зменшуючи їх ефективність та спотворюючи ідею справедливого, прозорого і неупередженого розподілу публічних фінансових ресурсів. Накреслено шляхи пересічення корупційних ризиків у державних 
фінансах та оцінено можливості i перспективи підвищення прозорості процедур державних закупівель.

Ключові слова: публічні закупівлі, ProZorro, корупція, фінансові ризики, бюджетний процес, фінансова безпека держави, індекс «ФОКС».

Antonenko Valentyna Mykolaivna PhD in Economics, Associate Professor of Management and Financial and Economic Security, DHEI «DonNTU», Shybankova Squa., 2, Pokrovsk, 85300, tel.: (06239)20-309, https://orcid.org/0000-0002-8220-5813

Servachuk Mykhailo Oleksandrovych Undergraduate, DHEI «DonNTU», Shybankova Squa., 2, Pokrovsk, 85300, tel.: (06239) 20-309

\title{
CORRUPTION RISKS IN PUBLIC PROCUREMENT AND THEIR IMPACT ON THE FINANCIAL SECURITY OF THE STATE
}

\begin{abstract}
Ukraine's European path and its efforts to become a modern civilized state, which would meet the principles of fair and transparent functioning of public finances, requires our country to make decisive changes in the field of public funding. However, the problems accumulated over decades in this area are holding back the prospects for Ukraine. One, and generally accepted, problem is the presence and sustainable perpetuation of corruption risks in the public finance system, which has a very negative impact, especially on the public procurement system. Therefore, it is too important today to identify these risks in order to contribute to the effective reform of public procurement. To do this, it is necessary to assess the level of corruption in the public procurement system, the current state of its operation, to systematize the possible risks of unfair behavior of entities at different stages of the tender. This would provide an opportunity to identify ways to minimize them in order to ensure adequate reform of tender legislation and practices to effectively address the above risks. To solve the set tasks, the work examines corruption risks in public procurement and determines their impact on state security. Attention is paid to the factors on which the potential capacity of Ukraine's financial resources under modern conditions depends, given the need to protect the financial interests of the state and society. The current legislation in the field of public finance regulation through the ProZorro system is studied and the analysis of the state of public procurement is carried out with the determination of the results and consequences of their implementation. Factors that negatively affect the public procurement process, reducing their efficiency and distorting the idea of fair, transparent and impartial distribution of public financial resources have been identified. The ways of overcoming corruption risks in public finances are outlined and the possibilities and prospects of increasing the transparency of public procurement procedures are assessed.
\end{abstract}

Keywords: public procurement, ProZorro, corruption, financial risks, budget process, financial security of the state, FOX index. 
Постановка проблеми. 16 вересня $2014^{\circ}$ р. Україна підписала Угоду про асоціацію з Європейським Союзом, в результаті чого в країні почався процес реформування економічної системи та адаптації іiї до міжнародних ринкових умов $^{\circ}[1]$. На базі цього діюча закупівельна система почала видозмінюватись: нові процедури закупівель переорієнтувалися на забезпечення прозорості і доступності отримання інформації, автоматизацію та спрощення процесів, комплексну систему оцінки i кваліфікації учасників торгів. Проте, запроваджені інновації не змогли вирішити проблеми із зловживаннями та існуванням корупційних ризиків, які були і досі залишаються найбільшим гальмом на шляху європейського курсу України. Ба більше - ця система породила нові схеми і варіанти різного роду зловживань, які спотворюють названу систему, знецінюють саму ідею прозорості і справедливості публічних фінансів та в цілому - відкидають країну у ще більшу корупційну прірву. Отож дослідження цього явища та пошук шляхів виходу з корупційної затяжної кризи $€$ надто актуальним і своєчасним питанням.

Аналіз останніх досліджень i публікацій. Базою для здійснення дослідження 3 обраної тематики стали праці провідних вчених, фахівців, науковців, зокрема: А. ${ }^{\circ}$ Бухтіарової, А. ${ }^{\circ}$ Войтовича і $\mathrm{C}^{\circ}{ }^{\circ}$ Мордовець ${ }^{\circ}[2]$,

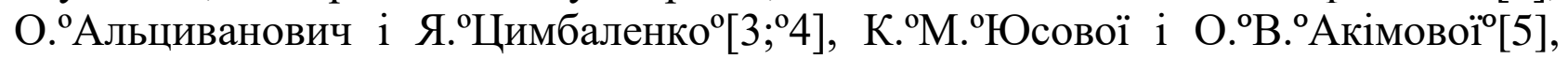
I. ${ }^{\circ}$ Бенько і С. ${ }^{\circ}$ Сисюк $[6]$ та інш. При цьому варто зазначити, що означена тема $\epsilon$ далекою до свого завершення і вимагає ретельних серйозних досліджень.

Метою статті $\epsilon$ оцінка рівня корупційності системи публічних закупівель, сучасного стану іï функціонування, систематизація можливих ризиків недоброчесної поведінки суб'єктів на різних етапах проведення торгів, а також визначення способів їх мінімізації з врахуванням тендерного законодавства та практики дієвої протидії.

Виклад основного матеріалу. Від початку незалежності України проблема корупції в державних закупівлях не втрачала своєї актуальності, бо іiі вирішення мало б впливати на ефективність проведення тендерів, забезпечило б належну якість необхідних товарів і послуг та можливість зекономити державні кошти. Заангажованість та високий корупційний рівень у державних закупівлях $\epsilon$ суттєвим фактором зниження рейтингів України в індексах сприйняття корупції та легкості ведення бізнесу, що погіршувало імідж країни та відчутно знижувало рівень іноземних інвестицій. У $2020^{\circ}$ p. показники України в індексі сприйняття корупції (Corruption Perceptions Index - CPI) зросли на 3 бали: країна посіла 117 місце серед 180 країн у списку СРI та отримала 33 бали зі 100 можливих. Країни - сусіди по рейтингу у списку, які теж отримали 33 бали, це - Сьєрра-Леоне, Сгипет, Замбія, Непал та африканська Есватіні (Свазіленд). Динаміка зміни індексу CPI України за $2013-2020^{\circ} \mathrm{pp}$. зображено на рис. $^{\circ} 1^{\circ}[7]$. Підвищення CPI України у $2020^{\circ}$ p. відбулось завдяки перезавантаженню Національного агентства 3 питань запобігання корупції та запуску Вищого антикорупційного суду - саме ці події 
завершили формування антикорупційної інфраструктури в Україні. У $2020^{\circ}$ р. запрацювали законодавчі зміни, прийняті ВРУ щодо відновлення відповідальності за незаконне збагачення; НАБУ отримало можливість здійснювати негласні слідчі дії, вступив в дію Закон України «Про внесення змін до Закону України «Про публічні закупівлі»

Незважаючи на певні переваги, є ряд ризиків, які знижують ефективність даної системи. В першу чергу, вважаємо, що загрозою є зниження кількості пропозицій на одні торги, що підтверджує недовіру учасників до системи електронних закупівель ProZorro та може бути спричинено рядом факторів, для аналізу яких в роботі використаємо діаграму Ісікави (cause-effect diagram, fishbone diagram) - графічний інструмент, що дозволяє наочно i систематизовано дослідити взаємозв'язки причин і їх наслідків[9]. Результати аналізу проблеми зниження кількості пропозицій на одні торги за допомогою діаграми Ісікави наведено на рис. 2.

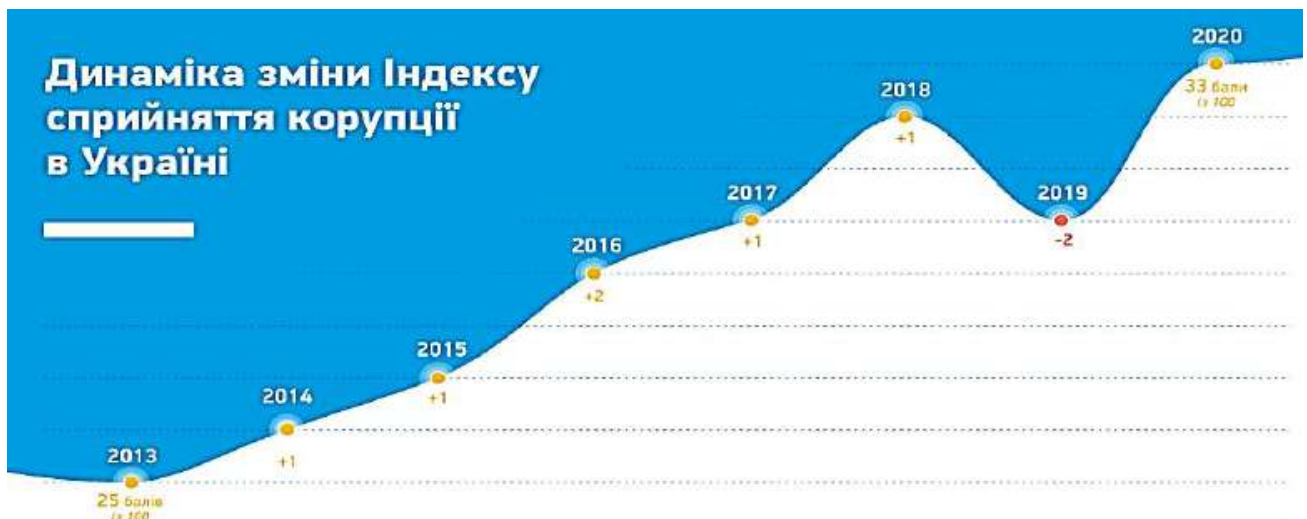

Pис. 1. Динаміка зміни Індексу СРІ України за 2013-2020p.p. [7]

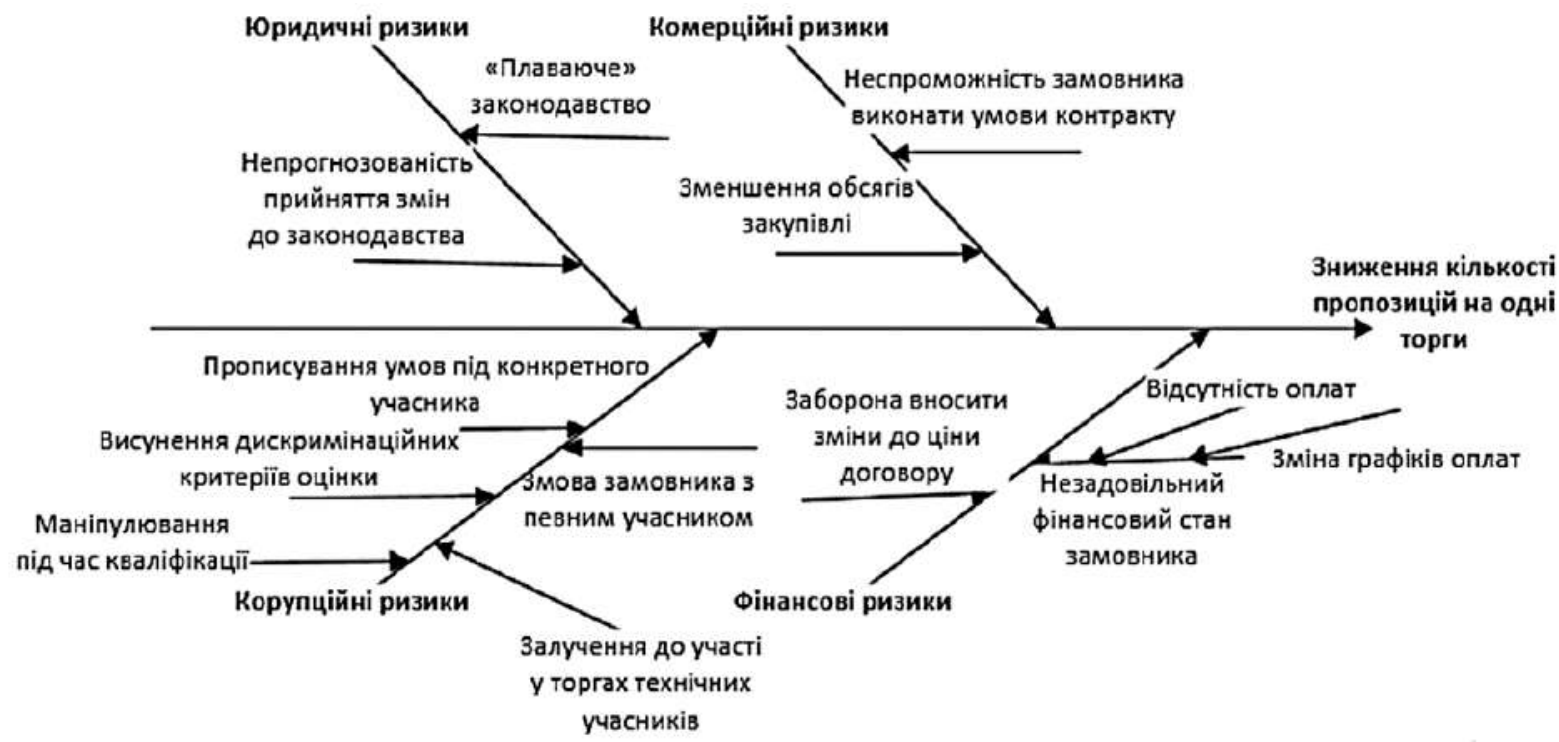

Pис. 2. Діаграма причинно-наслідкових зв'язків проблеми зниження кількості пропозицій на одні торги

Побудовано авторами на базі [9] 
Серйозним гальмуючим негативним фактором $є$ корупційні ризики. Вони можуть виникати на різних етапах проведення держзакупівель: на стадії підготовки та організації закупівлі, при кваліфікації учасників торгів, під час виконання замовлення. Досить вдало зроблена класифікація корупційних ризиків під час здійснення державних закупівель К. ${ }^{\circ}$ М. $^{\circ}$ Юсовою і О. ${ }^{\circ}$ М. ${ }^{\circ}$ Акімовою, які сміливо і відверто звернули увагу на корупційні прояви власних фінансових інтересів державних службовців, що має розглядатися, як: «використання службових повноважень чи пов'язаних 3 ними можливостей державних службовців, які полягають у порушенні врегульованої законодавством процедури придбання на конкурентній основі замовником товарів, робіт і послуг за публічні кошти; реалізація неправомірної вигоди, тобто особистих інтересів як виконавців, так і замовників у сфері публічних закупівель у різних формах без законних на те підстав; зниження ефективності використання публічних коштів та їх надмірна витрата через відсутність відкритої конкуренції між постачальниками товарів / виконавцями робіт і послуг» ${ }^{\circ}\left[5,{ }^{\circ} \mathrm{C} .{ }^{\circ} 41\right]$.

Фактично корупція - це використання посадовою особою своїх службових повноважень чи пов'язаних 3 ними можливостей для отримання власної вигоди, тому це провокує величезні збитки державі і суспільству - як фінансові, так і репутаційні. Основні корупційні схеми у сфері публічних закупівель та їхні ознаки наведені на рис. 3 . Необхідно зазначити, що корупційні ризики у сфері державних закупівель існують в багатьох інших країнах, де процедури протидії їм запроваджувалися раніше за Україну та які вже на сучасний період мають певний досвід боротьби 3 корупційними проявами. Так, «статистичні дані свідчать, що навколо публічних замовлень здійснюється близько 40\% усіх корупційних діянь у США, Західній Європі, Японії і в країнах Азії. Корупційні дії в системі публічних закупівель у будьякій країні приводять до значних втрат» $\left[6,{ }^{\circ} \mathrm{C} .{ }^{\circ} 85\right]$. Під впливом глобальної фінансової та економічної кризи саміт «групи 20-ти» у Пітсбурзі ще у вересні $2009^{\circ} \mathrm{p}$. оголосив міжнародну боротьбу 3 корупцією однією 3 трьох своїх стратегічних цілей. Отже, Україна має пройти певний шлях щодо опанування і оцінювання вагомості цієї проблеми і розробити дієві й ефективні заходи протидії корупційним діянням державних службовців, зважаючи на зарубіжний досвід у цій сфері.

Законодавство щодо публічних закупівель поки не в повній мірі працює в Україні i досить часто порушується самими замовниками. Найбільш розповсюдженим видом корупційних зловживань $\epsilon$ домовленості, які реалізуються учасниками щодо узгодження антиконкурентних дій; ця схема імітує конкурентну боротьбу та передбачає наперед погоджені координацію дій й тактику поведінки декількох суб'єктів господарювання, які направлені на 
сплановану перемогу одного з них. Ті замовники, яких цікавить не економія, а можливість укласти договір з наближеним постачальником, шукають будь-які способи уникнути аукціону. Одним із поширених методів зробити це є поділ предмета закупівлі, оскільки закупівлі, вартість яких нижча за 50 тис грн., можна проводити за прямими договорами й лише публікувати звіти про це в електронній формі. Так нечесні замовники без аукціону закуповують товари й послуги вартістю в сотні тисяч гривень, що підкреслює їх зневажливе ставлення до норм закону, хоча подібна практика прямо заборонена i за це передбачено штраф для замовника у розмірі від 25 тис до 50 тис грн..'8]. Окремі замовники державних закупівель також створюють штучні проблеми для так званих «небажаних» учасників. Одним з поширених методів порушень тендерних закупівель $є$ укладення змов й учасниками цих торгів, щоб зменшити ціну торгів. Як правило, їх учасники домовляються про максимальне обмеження ціни і визначають того, хто їх виграє. Особливо це проявляється при участі в цих торгах тільки двох учасників, які можуть бути пов'язаними між собою. Антимонопольний комітет України (АМКУ) бореться з подібними порушеннями за допомогою штрафів, але це поки не дає бажаних результатів. 


\section{Антиконкурентні узгоджені діі}

•цінові маніпуляції під час аукціону, ігнорування опції зниження вартості тендерної пропозиції;

•присутні прояви та ознаки спільної господарської діяльності учасників торгів

\section{Перемога одного 3 пов язаних учасників}

•учасники перебувають під контролем один одного чи третьої особи - неучасника торгів чи його представникаї;

•учасники торгів $є$ ФОП з однієї сім'ї;

-ігнорування ознаки пов'язаності учасників;

-присутні прояви та ознаки спільної господарської діяльності учасників торгів

Допуск до торгів суб єкта господарювання із забороною участі у процедурі

-Наявність учасника торгів у зведених відомостях про рішення органів АМКУ щодо визнання вчинення ним порушень законодавства про захист економічної конкуренції

\section{Завищення очікуваноі вартості}

•Вища за середньо ринкову ціна одиниці предмета закупівлі;

•умови договору щодо оплати та ії відтермінування з ризиком дискримінації;

•цінові маніпуляції під час аукціону;

-дискримінаційні кваліфікаційні вимоги в тендерній документації

\section{Недовиконання робіт}

-Умови договору щодо оплати з ризиком дискримінації;

- відмова у підписанні актів про виконані роботи замовником;

•відмова у завершенні певного виду робіт учасником

\section{Підміна предмету закупівлі}

•цінові маніпуляції під час аукціону;

- дискримінаційні кваліфікаційні вимоги в тендерній документації;

- якість товару, обсяг наданих послуг чи виконаних робіт

\section{Дискримінація}

•Вимога в тендерній документації щодо конкретної торговельної марки, моделі та особливостей ії комплектації; запатентовані вимоги певної торговельної марки щодо системи керування чи експлуатації;

•вимога в тендерній документації досвіду співпраці з певним замовником;

- поглиблена деталізація вимог до аналогічного договору;

- особливі вимоги до матеріально-технічної бази чи кваліфікації працівників Вибірковість при оцінці тендерних пропозищй

•Підозріло пасивна поведінка під час аукціону одного з учасників, який стає переможцем;

- поступове необ’єктивне відхилення тендерних пропозицій «непотрібних учасників», крім однієї

Pис. 3. Корупиійні схеми у сфері публічних закупівель та їхні ознаки

Як вже підкреслювалося, корупція деформувалася під впливом нової реформи публічних закупівель, що стало підгрунтям для виникнення принципово нових схем корупційних діянь. Головною ознакою системи ProZorro є відкритість та прозорість усього документообігу юридичних осіб до та після проведення тендерів, але частина корупційних злочинів як раз таки 
лежить на поверхні. Це система заплутаних вимог щодо документації, яку може витребувати замовник. Пунктом 1 ч. $^{\circ} 1$ ст. $^{\circ} 10$ Закону України «Про публічні закупівлі» вказано, що замовник самостійно оприлюднює в електронній формі через електронні майданчики оголошення про проведення конкурентних процедур закупівель, тендерну документацію та проєкт договору про закупівлю요. Оскільки законодавство не передбачає чітку систематизацію кваліфікаційної документації, замовник по суті має можливість зловживати цим правом. Якщо звернути увагу на практику публічних закупівель, можна виявити три варіанти оприлюднення тендерних вимог стосовно документів: 1) $)^{\circ}$ систематизація в окремому додатку тендерної документації; 2) ${ }^{\circ}$ систематизація тендерної документації, із витребуванням інших документів; 3) ${ }^{\circ}$ відсутність систематизації і документів в окремому додатку та розміщення відповідної інформації в окремих пунктах єдиного документу тендерної пропозиції. Остання варіація розміщення тендерних вимог щодо документації $є$ такою, що піддається максимальному сумніву щодо доброчесності замовника: оскільки тендерні вимоги мають можливість розміститися у будь-якій послідовності, у замовника $\epsilon$ можливість зловживати своїм правом та «замаскувати» деякі потрібні документи серед інших кваліфікаційних або технічних вимог, які передбачаються тендером. Через домовленість однієї юридичної особи з іншою, документообіг може перевищувати понад 50-100 сторінок, серед яких достатньо важко знайти інформацію стосовно документації, яку потрібно подати після перемоги у відповідному тендері, тому можуть виникати такі казуси, як дискваліфікація переможця публічної закупівлі через неподачу повної документації, котра вимагалася, бо іiі було достатньо важко відшукати серед десятків сторінок несистематизованих вимог! Наразі і спрощені закупівлі стають непростими, часто через самих замовників, які вимагають від учасників багато зайвих документів, що призводить до зростання скарг до Антимонопольного комітету України (АМКУ).

Одним iз «яскравих» індикаторів існування корупційного ризику та можливих корупційних дій може слугувати велика економія бюджетних коштів за результатами проведення окремих торгів. Такий результат підтверджує некоректний розрахунок потреби в коштах на початковому етапі, що спричиняє завищення очікуваної вартості предмету закупівлі. Вважаємо, що чим більша економія в результаті торгів - тим вищі корупційні ризики. Саме на етапі організації торгів відбуваються домовленості 3 наперед визначеним учасником-переможцем, який повідомляє реальну ціну та можливу суму зниження пропозиції. Цінове завищення вартості бюджету тендеру, яке зазвичай обгрунтовується організатором як результат кон'юнктурних коливань, становить 10-15\% - саме ця «надбавка» згодом виплачується зацікавленій особі замовника при перемозі необхідного учасника.

Згідно з Законом України «Про публічні закупівлі», спрощені закупівлі від 50 тис. грн. до порогу відбуваються без аукціону на зниження ціни. Якщо 
пропозиції подають два чи більше учасників, то аукціон відбувається; якщо один, то замовник може зразу підписати договір 3 ним. На рис. ${ }^{\circ} 4$ показано зміну питомої ваги конкурентних та неконкурентих процедур у $2020^{\circ} \mathrm{p}$. та за 11 місяців $2021^{\circ}$ p.; помісячна динаміка закупівель відповідно до процедур зображена на рис. 5 -6. Фіксується стала тенденція до збільшення конкурентних процедур, в $2021^{\circ} \mathrm{p}$. їхня частка зросла майже на $12^{\circ \%}$. У $2021^{\circ} \mathrm{p}$. на $13,65^{\circ} \%$ зросла питома вага надпорогових EU закупівель та на 4,17\% збільшилось укладання рамкових угод, проте зменшилась надпорогова UA закупівля на $3,76^{\circ} \%$ та надпорогова UA Оборони на $2,12^{\circ} \%{ }^{\circ}$ (рис. $\left.{ }^{\circ} 7-8\right)$.

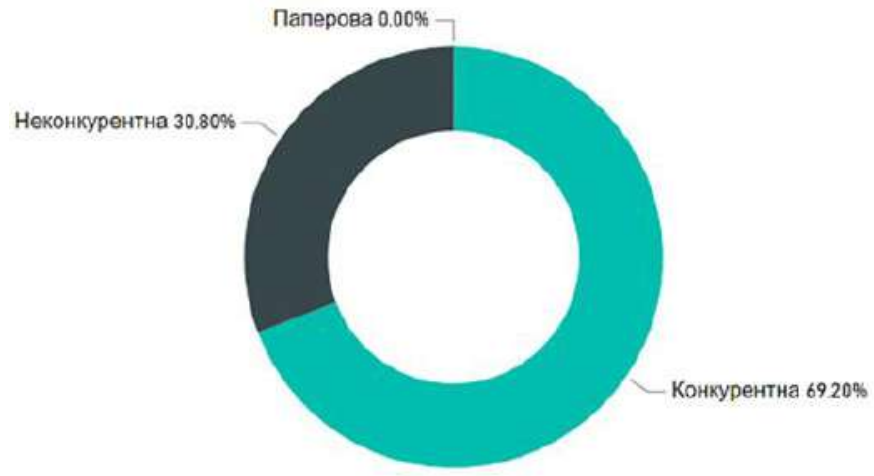

2020 рiк

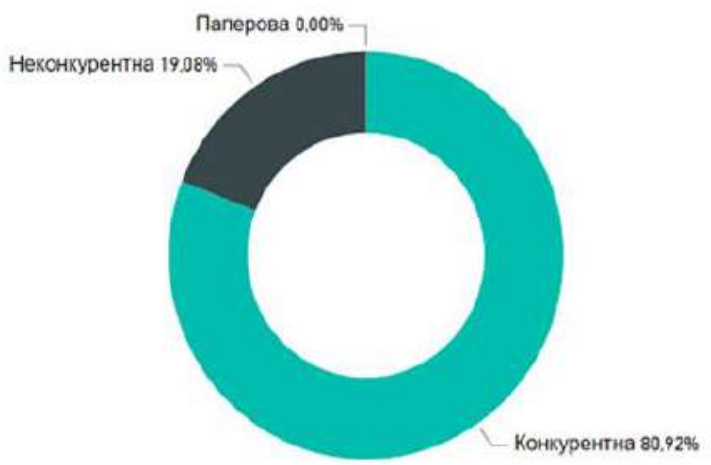

11 місяців 2021 року

Рис. 4. Питома вага проведених процедур у публічних закупівлях у 2020-2021 $\mathrm{pp} .{ }^{\circ} \%$

Побудовано авторами на базі [10]

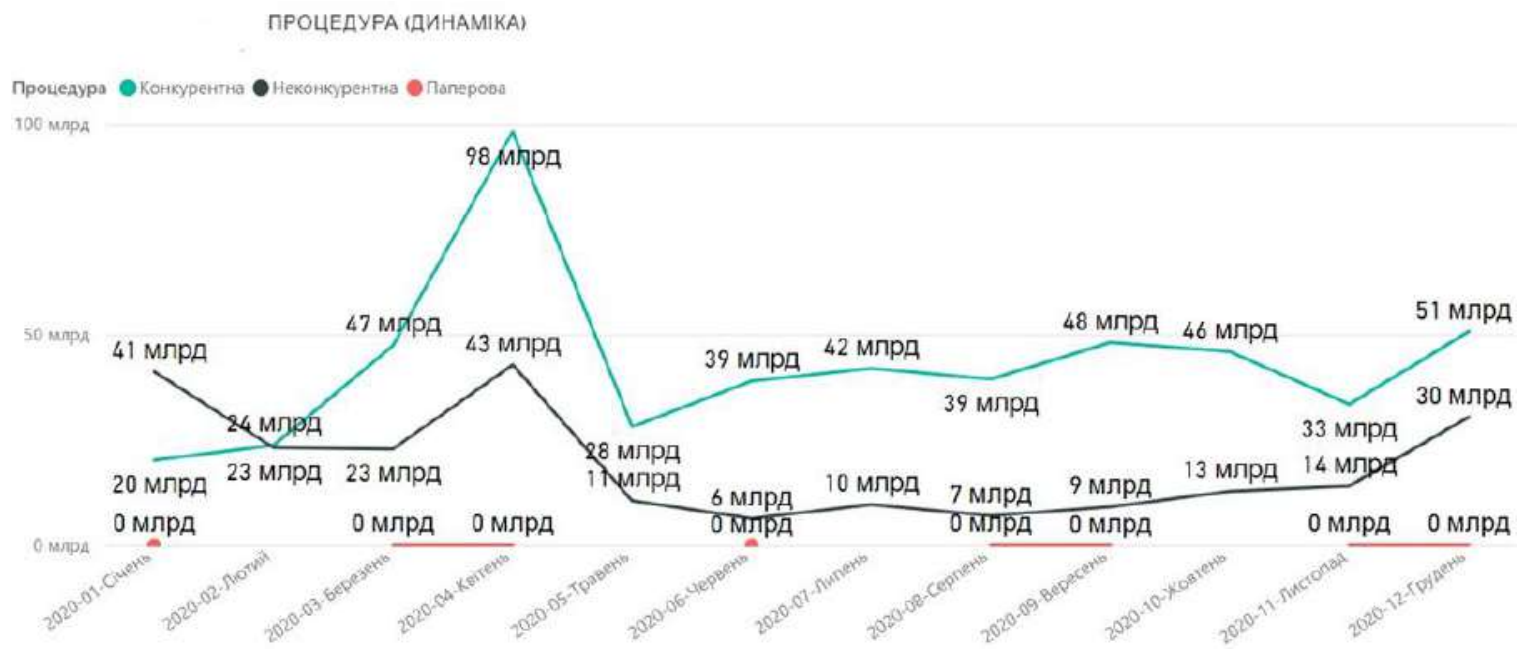

Pис. 5. Динаміка закупівельних процедур $2020^{\circ}$ р., млрд. грн.

Побудовано авторами на базі [10]

Важливим елементом реформи державних закупівель $є$ створення системи моніторингу. У грудні $2017^{\circ}$ p. ВРУ прийняла Закон України «Про внесення змін до закону України «Про публічні закупівлі» та деяких інших законів 
України щодо здійснення моніторингу закупівель» $[11]$, який дозволив Державній аудиторській службі України (ДАСУ) проводити моніторинг закупівель та попереджувати зловживання на всіх стадіях закупівлі. Законом запроваджено створення системи автоматичного ризик-менеджменту, який би сигналізував контролюючим органам про порушення.

ПРОЦЕЕДУРА (ДИНАМІКА)

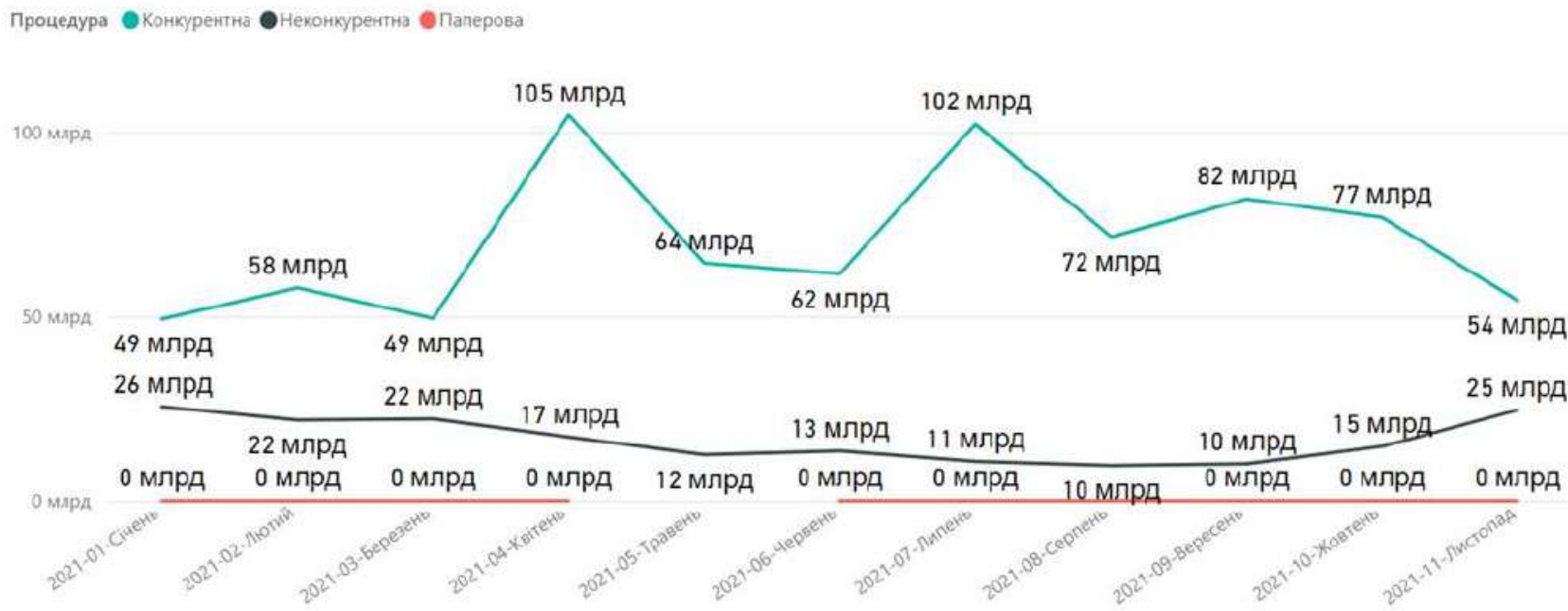

Рис. 6. Динаміка закупівельних прочедур за 11 міс. $2021^{\circ}$ p., млрд. грн. Побудовано авторами на базі [10]

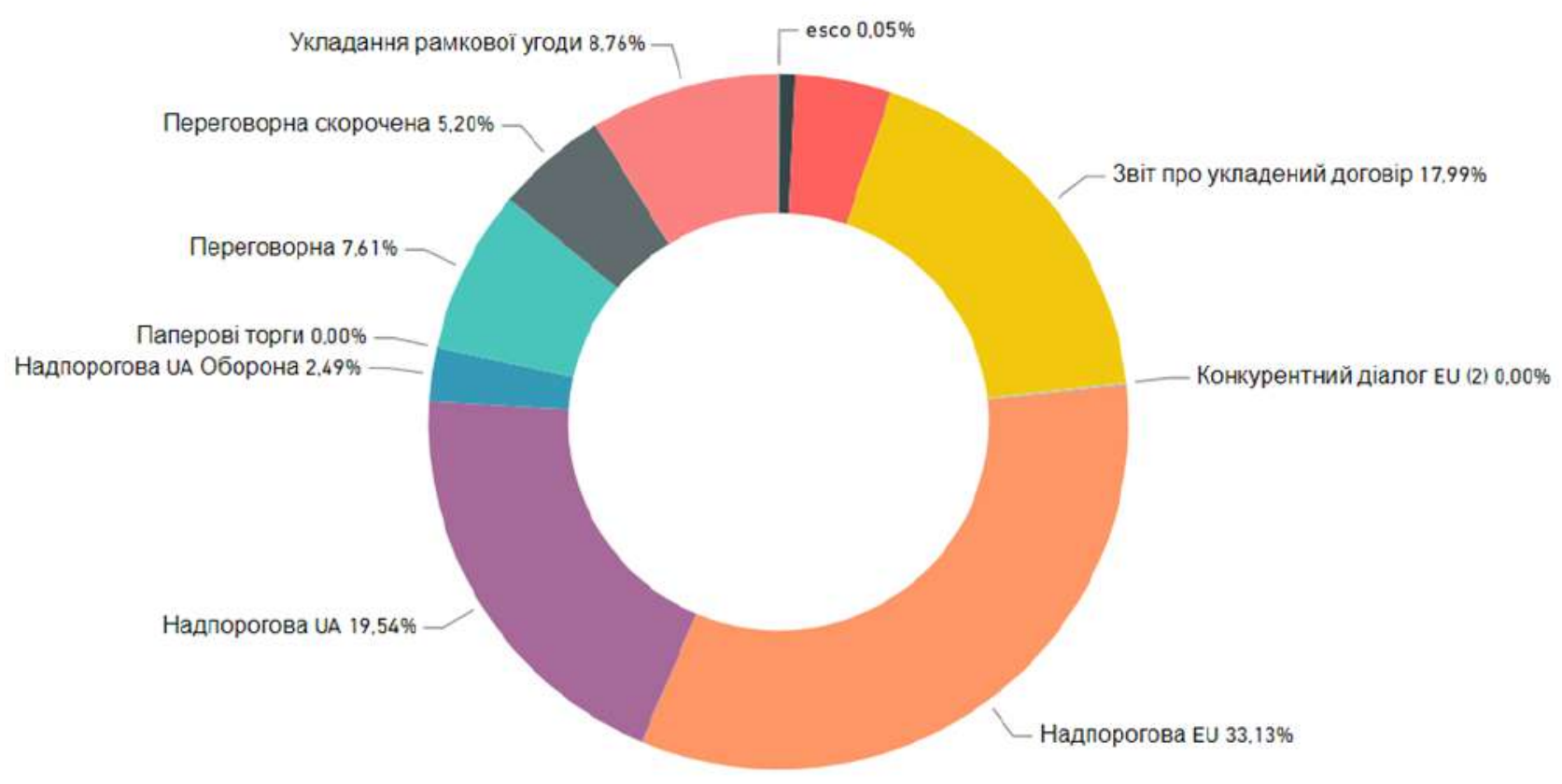

Puc. 7. Структура закупівель за типом проведених процедур у $2020^{\circ}$ p., ${ }^{\circ} \%$ 


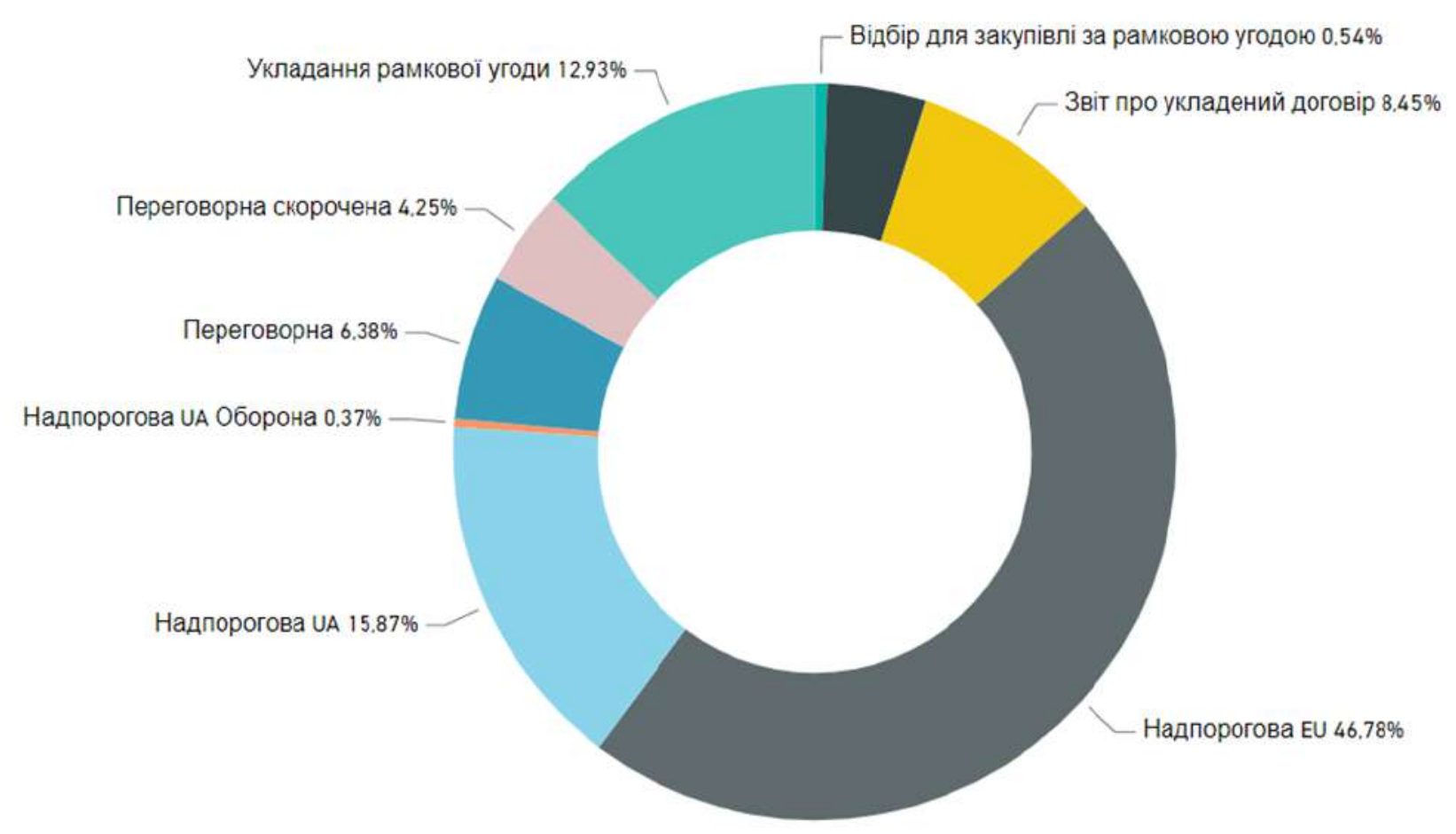

Puс. 8. Структура закупівель за типом проведених процедур за 11 міс. $2021^{\circ} \mathrm{p} .{ }^{\circ} \%$

Державні аудитори мають спеціальні електронні кабінети в системі ProZorro, де отримують інформацію щодо тендерів, які потрібно перевірити на основі ризик-індикаторів (порушення процедури проведення торгів, відсутність повноважень суб'єкта торгів, цифрових підписів, укладеного договору, завантажених тендерних документів, опису предмету закупівлі, перевищення строків розгляду, велика кількість лотів у тендері тощо). Всі дії аудиторів публічні і відображаються в системі. Фактично відбувається розрахунок індексу «ФОКС» («формалізовані ознаки корупційного ризику»); якщо індекс в межах від 21 до $40 \%$, то в закупівлі є певні незадовільні ознаки; якщо більше $40 \%$ - закупівля потребує уваги контролюючих органів. Більш детально методику наведено на рис. ${ }^{\circ}$ [12]. Замовник протягом трьох робочих днів має усунути виявлені порушення чи опублікувати свою незгоду i звернутись до суду, причому Закон зобов'язав закупівельників реагувати на рекомендації та зауваження в обов'язковому порядку. Створено спеціалізований моніторинговий портал закупівель Dozorro - онлайнплатформа, де будь-хто може залишити свої коментарі та інформацію державному замовнику чи постачальнику, громадськості та правоохоронним органам щодо проведення тендеру. Результатом цих дій стало те, що після запровадження нової редакції Закону України «Про публічні закупівлі»[13] приблизно $60 \%$ скарг 3 боку учасників стали задовольнятися. Крім того, для скорочення витрат часу для замовників в Prozorro Market запрацював запит 
ціни пропозицій, що дозволяє замовникам не лише купувати швидко, а й заощаджувати свої кошти.

Але, незважаючи на розвиток відповідного законодавства $\left[11 ;{ }^{\circ} 8{ }^{\circ} 13\right]$, однією з серйозних вад того середовища, в якому відбуваються перелічені вище зловживання, та й взагалі системною актуальною проблемою в державному регулюванні та контролі публічних закупівель, $\epsilon$ відсутність єдиного законодавчого акта, в якому б чітко визначалися повноваження, завдання й функції зазначених органів. Варто зауважити, що на сьогодні реалізація цих повноважень регулюється численними нормативно-правовими актами, положення яких подеколи можуть не гармоніювати один із одним, саме тому державний контроль системи публічних закупівель має суттєві недоліки. Бо у цьому випадку кількість не означає якість, а призводить до затягування усунення недоліків, виявлених під час перевірок. Так, аналіз нормативно-правової бази, що регулює сферу публічних закупівель, зроблений фахівцями Рахункової Палати України [14], підтверджує, що існує низка серйозних правових прогалин, які мають бути законодавчо врегульовані 3 метою вдосконалення функціонування системи публічних закупівель, іiі ефективності й прозорості.

Вважливим також є аспект, пов'язаний із захистом фінансових інтересів держави через врегулювання відносин між державою, 3 однієї сторони, та виконавцем держзамовлення і його замовником - 3 іншої: першим суб'єктом вважаємо державу, інтереси якої необхідно захищати, другим - конкретних осіб, які мають свої власні фінансові інтереси, відмінні від інтересів держави. Дається взнаки і викликає суттєві негативні наслідки відсутність достатньої відповідальності за порушення законодавства у сфері державних закупівель названими особами, які, переслідуючи свої власні інтереси, припускаються конфлікту інтересів на користь забезпечення власних і нехтування державних. 


\section{МЕТОДИКА РОЗРАХУНКУ}

ІНДЕКСУ "ФОКС (Формалізовані Ознаки Корупційної Складовоі) для оцінки якості переможця державного тендеру особи віком понад 1 рік

\begin{tabular}{|c|c|c|}
\hline \multicolumn{3}{|c|}{ 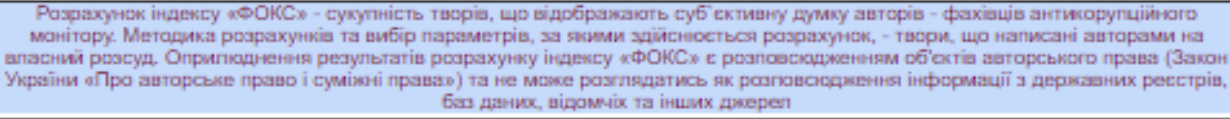 } \\
\hline Показник & $\begin{array}{c}\text { Bплие на } \\
\text { ФОКС }\end{array}$ & Чинна основа показника \\
\hline \multicolumn{3}{|c|}{ 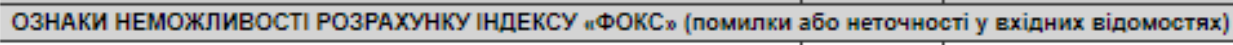 } \\
\hline 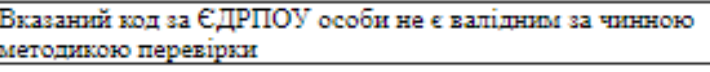 & $+51 \%$ & $\begin{array}{l}\text { Помилка неточність у } \\
\text { наданому коді }\end{array}$ \\
\hline Особа не $є$ резидентом України & $+21 \%$ & $\begin{array}{c}\text { Biдсутна звітність } \\
\text { нерезидентів }\end{array}$ \\
\hline Юридична особа є новим підрозділом а6о фітіею & $+10 \%$ & $\begin{array}{c}\text { Відсутня публична } \\
\text { звітність }\end{array}$ \\
\hline
\end{tabular}

КРИТИЧНІ ОЗНАКИ ДЛЯ ІНДЕКСУ «ФОКС

Наявне рішеннл AMKY про порушеннл зақонодавства про захист економ⿰іної монхуренці:

\begin{tabular}{|c|c|c|}
\hline & \multirow{3}{*}{$\begin{array}{rr}\text { - } & \text { оскарження } \\
\text { - } & \text { E процесі оскарженна } \\
\text { - } & \text { 6ез оскарження }\end{array}$} & $+10 \%$ \\
\hline & & $+30 \%$ \\
\hline & & $+50 \%$ \\
\hline \multirow{2}{*}{\multicolumn{2}{|c|}{$\begin{array}{l}\text { Перебування в пронесі припиненна діяльності: } \\
\text { зитт, перетворення, поділ } \\
\text { - зопо } \\
\text { завершення діяпності }\end{array}$}} & $+30 \%$ \\
\hline & & $+50 \%$ \\
\hline
\end{tabular}

3a mn. 7,8 vact. 1 cr. 17 Завону Ухраїни публіпні захупівлі

\begin{tabular}{|c|c|}
\hline \multicolumn{2}{|c|}{ ФОРМАЛІЗОВАНІ ОЗНАКИ ДЛЯ ІНДЕКСУ «ФОКС } \\
\hline \multicolumn{2}{|l|}{ Ознаки сумнівної якості } \\
\hline 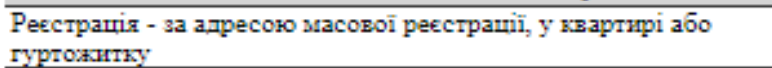 & $+5 \%$ \\
\hline $\begin{array}{l}\text { Bмазаний основний телефон - мобіпьнй а6о розтапований в } \\
\text { іншому населеному пункті }\end{array}$ & $+5 \%$ \\
\hline Керізних та засновник $е$ одніею особою & $+5 \%$ \\
\hline Засновник володіе $100 \%$ статутного фонду & $+5 \%$ \\
\hline Статутний фонд близький до мінімального (менше 10000 грн) & $+5 \%$ \\
\hline $\begin{array}{l}\text { В останні півроху змінювалась адреса, i/a6o розмір статутного } \\
\text { фонду, i/a6o засновнизи }\end{array}$ & $+5 \%$ \\
\hline
\end{tabular}

за част. 2 cr. 16 част. 5 ст. 28 Замону Украіни

«ро публінгі saxymizлis фонду, i/a6o засновнихи

\begin{tabular}{|c|c|c|}
\hline \multicolumn{3}{|c|}{ Ознаки неефективної господарчої діяльності } \\
\hline Податковий боракник & $+30 \%$ & \multirow{6}{*}{$\begin{array}{c}\text { за част.2 ст.16 3акону } \\
\text { України «Про публічні } \\
\text { захупівлі» }\end{array}$} \\
\hline С тійке зростання або перевитення 30608 лзань над доходом & $+10 \%$ & \\
\hline 36иткова фінансово-господарча діяльність & $+15 \%$ & \\
\hline $\begin{array}{l}\text { Тендерні кошти є значною часткок (понад 60\%) в структурі } \\
\text { доходу }\end{array}$ & $+10 \%$ & \\
\hline Hизьхі або негатинні показники рентабельності & $+10 \%$ & \\
\hline Незадовітна опінка фінансового стану & $+10 \%$ & \\
\hline
\end{tabular}

\section{Ознаки можливої неспроможності виконання своїх зобов'язань}

\begin{tabular}{|c|c|c|}
\hline $\begin{array}{l}\text { Тендерні кошти на } 100 \% \text { більше суми основних засобів та } \\
\text { нематеріальншх активів }\end{array}$ & $+10 \%$ & \multirow{3}{*}{ 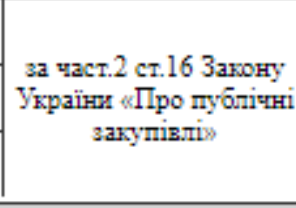 } \\
\hline $\begin{array}{l}\text { Tендерні кошти в } 3 \text { та більше разів перевінують останній річний } \\
\text { дохід }\end{array}$ & $+5 \%$ & \\
\hline 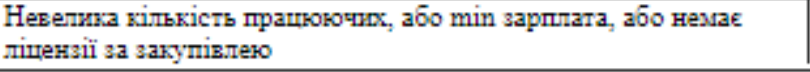 & $+5 \%$ & \\
\hline \multicolumn{3}{|c|}{ Ознаки негативної ділової репутації особи } \\
\hline Незавершені виконавчі провадження шодо особи & $+15 \%$ & \multirow{3}{*}{ 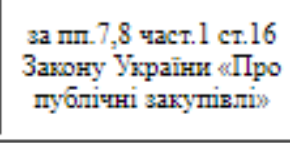 } \\
\hline Оскарження в суді санкцій з боку фіскальних органів & $+5 \%$ & \\
\hline Позови до особи в судах з боку інших осі6 & $+5 \%$ & \\
\hline \multicolumn{3}{|l|}{ ВИСНОВОК } \\
\hline Індехс ФОКС задовільний & $0 . .20 \%$ & Значення в зеленій зоні \\
\hline Iндекс ФОКС мае певну хількість незадовільних ознах & $21 \ldots 40 \%$ & Значення в ховтй̆ зоні \\
\hline Iндекс ФОКС незадовітьний & $41 \ldots 100 \%$ & Значення в червоній зоні \\
\hline
\end{tabular}

Pис. 9. Методика розрахунку індексу «ФОКС» 
Вважаємо абсолютно неприпустимим той факт, що законодавчо передбачена лише адміністративна відповідальність за вчинені порушення, що зазвичай незіставна із завданою державі шкодою. За статистикою, до відповідальності у сфері публічних закупівель притягується мізерна кількість порушників. Наведемо показовий приклад: Антимонопольним комітетом розглядалася скарга про безпідставне відхилення учасника закупівлі; у разі задоволення цієї скарги порушник був зобов'язаний скасувати рішення про відхилення цього учасника, однак ніякої відповідальності за неправомірні дії не поніс, хоча Кодекс України про адміністративні правопорушення чітко передбачає відповідальність за це порушення $[15]$. Тож державі необхідно змінити механізм відповідальності; наприклад, запровадити норму, за якою органи державної аудиторської служби мали б можливість перевіряти законність дій порушника, стосовно якого виніс рішення Антимонопольний комітет, i за результатами перевірки, у разі наявності доказів, зверталися до суду.

Отож, в цілому проблема пересічення корупційних зловживань в системі державних закупівель є надто актуальною і такою, що викликає до себе велику увагу і потребує свого скорішого кардинального вирішення. Погоджуємося із тим, що ця проблема визнана економічним фронтом ${ }^{\circ}[16]$, на якому, додамо, має захищатися держава від корупційних зловживань та наразі вирішується майбутня доля нашої країни. 3 цього приводу доречно згадати, що ще 31 жовтня $2003^{\circ}$ p. Генеральною Асамблеєю ООН була ухвалена Конвенція ООН проти корупції, яка набула чинності 14 грудня $2005^{\circ}$ p. Вона встановлює загальні принципи, стандарти, процеси та практики антикорупційних зусиль на національному рівні, сприяє міжнародній співпраці через гармонізацію нормативно-правових баз для ефективного правозастосування і встановлення механізмів взаємодопомоги. I хоча Україна намагається стрімко інтегруватися в $\mathrm{CC}$, фокусуючись на імплементації директив $\mathrm{CC}$ у сфері державних закупівель до українського законодавства, але, поки що діюча українська практика у цьому сенсі не відповідає існуючим вимогам. ${ }^{\circ}$ [4]

Одним 3 можливих варіантів пересічення таких корупційних схем у нашій державі може слугувати законодавство Південної Кореї і, відповідно, електронна система публічних закупівель «KONEPS» (Korea Online EProcurement System), та додатки до даної системи. Закони Республіки Корея про публічні закупівлі вимагають чіткої систематизації усіх вимог стосовно тендерної документації [17]. У вказаних документах, на практиці, предмет та зміст відповідної публічної закупівлі викладено достатньо лаконічно, що сприяє усуненню виникнення труднощів як у національних постачальників, так і зарубіжних. Треба зробити акцент на спеціальних додатках, які доповнюють систему «KONEPS», але не є іiі складовою. Такі додатки передбачені для збору аналітичної інформації, яка, у свою чергу, потрібна для отримання систематизованого переліку документації постачальникам. Виходячи 3 успішної практики застосування ІКТ Південною Кореєю, доцільно використати 


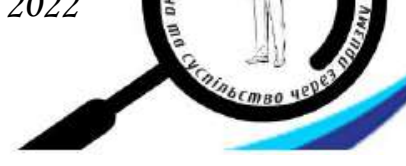

цей досвід, а саме: а) ${ }^{\circ}$ на законодавчому рівні внести поправки до Закону України «Про публічні закупівлі» стосовно зобов’язань замовників у цій галузі та систематизувати усі потрібні вимоги, які стосуються документації, в окремий додаток; б) ${ }^{\circ}$ на рівні IКТ утворити окрему систему на базі платформи «Дія», яка буде доповнювати систему ProZorro. Така практика має поліпшити ситуацію щодо корупційних ризиків та зменшити бюрократичне навантаження на юридичних осіб. Оскільки постачальники одразу зможуть бачити, які кваліфікаційні та технічні вимоги стосовно документації вони завантажили, а які ще ні, тим самим було б скасовано хоча б одна лазівка для проникнення корупційно зацікавлених осіб у процедури державних закупівель.

Висновки. Кількість закупівельних процедур 3 кожним роком збільшується. В цілому в останні роки неурядові громадські організації беруть активну участь у реформуванні системи закупівель шляхом участі у робочих групах з розробки змін до законодавства у сфері закупівель, здійснення їх моніторингу, проведенні навчальних та просвітницьких заходів тощо. Незважаючи на великі зрушення в сфері публічних закупівель, залишається ще багато перешкод, щоб мінімізувати іхній вплив, тому творці системи постійно створюють додаткові інструменти для учасників.

Сучасне реформування сфери публічних закупівель із впровадженням електронної системи ProZorro, безумовно, є великим кроком уперед для подолання корупційних проявів та полегшення роботи юридичних осіб у тендерній процедурі. Проте, з появою електронної системи ProZorro були виявлені нові корупційні ризики, які під впливом нової тенденції інформатизації були деформовані та скриті від очей громадян.

Функціонал публічних закупівель та їхня роль в соціально-економічних процесах країни визначають проблему протидії корупційним проявам у цій сфері однією з нагальних і головних в системі сучасних реформ. Введення в дію нових положень тендерного законодавства повинно знизити рівень корупційних ризиків під час організації та проведення торгів. Проте синергетичний вплив на мінімізацію дії корупційної складової, крім використання психологічних, технічних і регламентних інструментів, потребує подальшої активізації діяльності саме контролюючих та правоохоронних органів як інституцій, які покликані реалізовувати репресивну компоненту протидії недоброчесним домовленостям у сфері публічних закупівель. Існування корупційних ризиків у сфері закупівель свідчить про динамічну адаптацію кримінологічних суб’єктів до новел законодавства, що у свою чергу, обумовлює необхідність подальшого пошуку ефективних механізмів протидії детермінантам корупції та визначає перспективи нових досліджень.

\section{Лimepamypa:}

1. Угода про Асоціацію між Україною, з однієї сторони, та Європейським Союзом, Європейським Співтовариством 3 атомної енергії і їхніми державами-членами, 3 іншої сторони. URL: https://www.kmu.gov.ua/diyalnist/yevropejska-integraciya/ugoda-pro-asociacyu. 
2. Бухтіарова А., Войтович А., Мордовець Є. Науково-методичні підходи до трактування поняття «корупція» у системі публічних фінансів. Економіка. Фінанси. Право. 2018. № 5. С. 10-14 (дата звернення: 15.12.2021).

3. Альциванович О., Цимбаленко Я. Теоретико-категоріальний аналіз поняття публічних закупівель та корупційних ризиків при їх здійсненні в Україні. Аспекти публічного управління. 2018. Т. 6. № 9. С. 92-103. URL: http://nbuv.gov.ua/UJRN/aplup_2018_6_9_12 (дата звернення: 15.12.2021).

4. Альциванович О., Цимбаленко Я. Міжнародний та європейський досвід уникнення корупційних ризиків під час здійснення публічних закупівель. Аспекти публічного управління. 2018. Т. 6. № 10. C. 62-73. URL: http://nbuv.gov.ua/UJRN/aplup_2018_6_10_10 (дата звернення: 15.12.2021).

5. Юсова К.М., Акімова О.М. Корупційні прояви у системі публічних закупівель та їх класифікація. Економіка та управління національним господарством. 2020. Вип. 11-1. С. 37-42. URL: http://ei-journal.in.ua/index.php/journal/article/view/263 (дата звернення: 15.12.2021).

6. Бенько I., Сисюк С. Корупція у сфері публічних закупівель: форми прояву та засоби протидії. Причорноморські економічні студіï. 2019. Вип. 38 (2). C. 84-87. URL: http://bses.in.ua/journals/2019/38_2_2019/19.pdf (дата звернення: 15.12.2021).

7. BBC Ukrainian. Індекс сприйняття корупції. URL: https://www.bbc.com/ukrainian/ news-55837512 (дата звернення: 13.12.2021).

8. Про внесення змін до Закону України «Про публічні закупівлі» та деяких інших законодавчих актів України щодо вдосконалення публічних закупівель : Закон України від 19.09.2019º. № 114-IX. URL: https://zakon.rada.gov.ua/laws/show/114-20\#Text.

9. Алексеев А. Диаграмма Ишикавы как метод структурного анализа. 2009. URL: http://www.itexpert.ru/rus/ITEMS/77-14_Ishikava_1_1.pdf (дата звернення: 10.12.2021).

10. Модуль аналітики закупівель «Антикорупційний монітор». URL: http://acm-ua.org/ (дата звернення: 10.12.2021).

11. Про внесення змін до Закону України «Про публічні закупівлі» та деяких інших законів України щодо здійснення моніторингу закупівель» : Закон України від 21.12.2017p. № 2265-VIII. URL: https://zakon.rada.gov.ua/laws/show/2265-19\#Text.

12. Модуль аналітики закупівель «Антикорупційний монітор». Методика розрахунку індексу «ФОКС». URL: http://acm-ua.org/Metodics_uo.htm (дата звернення: 10.12.2021).

13.Про внесення змін до Закону України «Про публічні закупівлі» та інших законів України щодо вдосконалення системи функціонування та оскарження публічних закупівель» : Закон України від $30.06 .2021^{\circ}$ p. № 1530-IX. URL: https://zakon.rada.gov.ua/laws/show/1530-20\#Text/.

14. Звіт про результати аналізу щорічного звіту Міністерства розвитку економіки, торгівлі та сільського господарства України, що містить аналіз функціонування системи публічних закупівель (щодо кількісних і вартісних показників закупівель у розрізі процедур і предметів закупівель, рівня конкуренції, кількості скарг) та узагальнену інформацію про результати здійснення контролю у сфері закупівель. Затв. рішенням Рахункової палати від 08.06.2021p. № 12-2. Київ, 2021. 53 c. URL: http://rp.gov.ua/upload-files/Activity/Collegium/ 2021/12-2_2021/Zvit_12-2_2021.pdf (дата звернення: 27.12.2021).

15. Кодекс України про адміністративні правопорушення від 07.12.1984 № 80731-Х. URL: https://zakon.rada.gov.ua/laws/show/80731-10\#Text.

16. Україна проти корупції: Економічний фронт. Економічна оцінка антикорупційних заходів у 2014-2018 pp. Дніпро: Середняк Т.К., 2018. 85 c. URL: Anticorruption_Report_Ukr_.pdf (дата звернення: 15.12.2021).

17. Синицький К., Олійник Я., Міхальова М., Лущан Т. Кращі практики впровадження електронного урядування: зарубіжний досвід. Методичні матеріали до навч. дисц.: «Теоретико-методологічні, організаційні та інституційні основи електронного урядування». 
Київ: Національна академія державного управління при Президентові України, 2010. 166с. URL: https://ktpu.kpi.ua/wp-content/uploads/2016/02/Krashhi-praktiki-vprovadzhennya-elektronnogouryaduvannya_zarubizhnij-dosvid.pdf (дата звернення: 12.12.2021).

\section{References:}

1. Uhoda pro Asotsiatsiiu mizh Ukrainoiu, z odniiei storony, ta Yevropeiskym Soiuzom, Yevropeiskym Spivtovarystvom z atomnoi enerhii i yikhnimy derzhavamy-chlenamy, z inshoi storony [The Association Agreement between Ukraine, of the one part, and the European Union, the European Atomic Energy Community and their Member States, of the other part]. Retrieved from: https://www.kmu.gov.ua/diyalnist/yevropejska-integraciya/ugoda-pro-asociacyu [in Ukrainian].

2. Bukhtiarova, A., Voitovych, A., \& Mordovets, E. (2018). Naukovo-metodychni pidkhody do traktuvannia poniattia «koruptsiia» $u$ systemi publichnykh finansiv [Scientific and methodological approaches to the interpretation of the concept of «corruption» in the system of public finance]. Ekonomika. Finansy. Pravo - Economy. Finances. Right. 5. 10-14 [in Ukrainian].

3. Altsyvanovych, O., \& Tsymbalenko, J. (2018). Teoretyko-katehorialnyi analiz poniattia publichnykh zakupivel ta koruptsiinykh ryzykiv pry yikh zdiisnenni v Ukraini [Theoretical and categorical analysis of the concept of public procurement and corruption risks in their implementation in Ukraine]. Aspekty publichnoho upravlinnia - Aspects of public administration. 6 (9), 92-103. Retrieved from: http://nbuv.gov.ua/UJRN/aplup_2018_6_9_12 [in Ukrainian].

4. Altsyvanovych, O., \& Tsymbalenko, J. (2018). International and European experience in avoiding corruption risks in public procurement [International and European experience in avoiding corruption risks in public procurement]. Aspekty publichnoho upravlinnia - Aspects of public administration. 6 (9), 62-73. Retrieved from: http://nbuv.gov.ua/UJRN/aplup_2018_6_10_10 [in Ukrainian].

5. Yusova, K.M, \& Akimova, O.M. (2020). Koruptsiini proiavy u systemi publichnykh zakupivel ta yikh klasyfikatsiia [Corruption manifestations in the public procurement system and their classification]. Ekonomika ta upravlinnia natsionalnym hospodarstvom - Economics and management of the national economy, 11-1. 37-42. Retrieved from: http://ei-journal.in.ua/ index.php/journal/article/view/263 [in Ukrainian].

6. Benko, I., \& Sysyuk, S. (2019). Koruptsiia u sferi publichnykh zakupivel: formy proiavu ta zasoby protydii [Corruption in the field of public procurement: forms of manifestation and means of counteraction]. Prychornomorski ekonomichni studii - Black Sea Economic Studies, 38 (2). 84-87. Retrieved from: http://bses.in.ua/journals/2019/38_2_2019/19.pdf [in Ukrainian].

7. BBC Ukrainian. Indeks spryiniattia koruptsii [BBC Ukrainian Corruption Perceptions Index]. Retrieved from: https://www.bbc.com/ukrainian/news-55837512 [in Ukrainian].

8. Pro vnesennia zmin do Zakonu Ukrainy «Pro publichni zakupivli» ta deiakykh inshykh zakonodavchykh aktiv Ukrainy shchodo vdoskonalennia publichnykh zakupivel : Zakon Ukrainy vid 19.09.2019 ${ }^{\circ}$. № 114-IX [On Amendments to the Law of Ukraine «On Public Procurement» and some other legislative acts of Ukraine on improving public procurement: Law of Ukraine of September 19 2019, № 114-IX]. Retrieved from: https://zakon.rada.gov.ua/laws/show/114-20\#Text [in Ukrainian].

9. Alekseev, A. (2009). Dyahramma Yshykavы kak metod strukturnoho analyza [Ishikawa diagram as a method of structural analysis]. Retrieved from: http://www.itexpert.ru/rus/ITEMS/7714_Ishikava_1_1.pdf [in Russian].

10. Modul analityky zakupivel «Antykoruptsiinyi monitor». [Procurement Analytics Module «Anti-Corruption Monitor»]. Retrieved from: http://acm-ua.org/ [in Ukrainian].

11. On Amendments to the Law of Ukraine «On Public Procurement» and some other laws of Ukraine on monitoring of procurement»: Law of Ukraine of 21.12.2017 № 2265-VIII. URL: https://zakon.rada.gov.ua/ laws / show / 2265-19 \# Text. 
12. Modul analityky zakupivel «Antykoruptsiinyi monitor». Metodyka rozrakhunku indeksu «FOKS» [Procurement Analytics Module «Anti-Corruption Monitor». Methodology for calculating the index «FOX»]. Retrieved from: http://acm-ua.org/Metodics_uo.htm [in Ukrainian].

13. Pro vnesennia zmin do Zakonu Ukrainy «Pro publichni zakupivli» ta inshykh zakoniv Ukrainy shchodo vdoskonalennia systemy funktsionuvannia ta oskarzhennia publichnykh zakupivel» : Zakon Ukrainy vid 30.06.2021r. № 1530-IX [On Amendments to the Law of Ukraine «On Public Procurement» and other Laws of Ukraine on Improving the System of Functioning and Appeals of Public Procurement»: Law of Ukraine of June 30, 2021. № 1530-IX]. Retrieved from: https://zakon.rada.gov.ua/laws/show/1530-20\#Text/ [in Ukrainian].

14.Zvit pro rezultaty analizu shchorichnoho zvitu Ministerstva rozvytku ekonomiky, torhivli ta silskoho hospodarstva Ukrainy, shcho mistyt analiz funktsionuvannia systemy publichnykh zakupivel (shchodo kilkisnykh i vartisnykh pokaznykiv zakupivel u rozrizi protsedur i predmetiv zakupivel, rivnia konkurentsii, kilkosti skarh) ta uzahalnenu informatsiiu pro rezultaty zdiisnennia kontroliu u sferi zakupivel. Zatv. rishenniam Rakhunkovoi palaty vid 08.06.2021r. № 12-2. [Report on the results of the analysis of the annual report of the Ministry of Economic Development, Trade and Agriculture of Ukraine, which contains an analysis of the public procurement system (on quantitative and cost indicators of procurement in terms of procurement procedures and subjects, level of competition, number of complaints) and summary information on control results in the field of procurement. Approved by the decision of the Accounting Chamber dated 08.06.2021 № 12-2]. Retrieved from: http://rp.gov.ua/uploadfiles/Activity/Collegium/2021/12-2_2021/Zvit_12-2_2021.pdf [in Ukrainian].

15. Kodeks Ukrainy pro administratyvni pravoporushennia vid 07.12.1984 № 80731-X [Code of Ukraine on Administrative Offenses of 07.12.1984 № 80731-X]. Retrieved from: https://zakon.rada.gov.ua/laws/show/80731-10\#Text [in Ukrainian].

16. Ukraina proty koruptsii: Ekonomichnyi front. Ekonomichna otsinka antykoruptsiinykh zakhodiv u 2014-2018 $\mathrm{rr}$. [Ukraine Against Corruption: The Economic Front. Economic evaluation of anti-corruption measures in 2014-2018]. (2018). Dnipro: Serednyak T.K. 85 p. Retrieved from: Anticorruption_Report_Ukr_pdf [in Ukrainian].

17.Sinitsky, K., Oliynyk, Ja., Mikhalova, M., \& Lushchan, T. (2010). Krashchi praktyky vprovadzhennia elektronnoho uriaduvannia: zarubizhnyi dosvid. Metodychni materialy do navch. dysts.: «Teoretyko-metodolohichni, orhanizatsiini ta instytutsiini osnovy elektronnoho uriaduvannia» [Best practices in implementing e-government: foreign experience. Methodical materials for teaching. Dissertation: «Theoretical and methodological, organizational and institutional foundations of e-government»]. Kyiv: Natsionalna akademiia derzhavnoho upravlinnia pry Prezydentovi Ukrainy. Retrieved from: https://ktpu.kpi.ua/wp-content/uploads/2016/02/ Krashhi-praktiki-vprovadzhennya-elektronnogo-uryaduvannya_zarubizhnij-dosvid.pdf [in Ukrainian]. 